\title{
Optimal Concentrations of Lysine, Methionine, and Threonine in Milk Replacers for Calves Less than Five Weeks of Age
}

\author{
T. M. Hill, ${ }^{11}$ H. G. Bateman II, ${ }^{\star}$ J. M. Aldrich, ${ }^{*}$ R. L. Schlotterbeck, ${ }^{\star}$ and K. G. Tanan† \\ *Akey, Nutrition and Research Center, PO Box 5002, Lewisburg, OH 45338 \\ †Provimi Research and Innovation Centre, Lenneke Marelaan 2, Sint-Stevens-Woluwe B1932, Belgium
}

\begin{abstract}
The AA requirements of herd-replacement calves less than 5 wk old and fed milk replacers are not clearly defined and have been estimated in a limited number of studies using milk-fed calves ranging from 5 to 20 wk of age. The objective of these 4 studies was to investigate the effect of supplementing milk replacers containing 24 to $28 \%$ crude protein (CP; from milk sources) and $17 \%$ fat with Lys, Met, and Thr to estimate the optimum requirements for calves less than $5 \mathrm{wk}$ of age. Holstein bull calves (initially 3 and $4 \mathrm{~d}$ old, $43 \pm 1 \mathrm{~kg}$ of body weight, BW) were fed an $18 \% \mathrm{CP}$ (as-fed) starter ad libitum and weaned at 31 to $32 \mathrm{~d}$ of age (28-d studies). Calves were housed in an unheated, curtain-sided nursery. In study 1, 6 milk replacer treatments were fed based on the combination of $3 \mathrm{CP}$ concentrations (24, 26 , and $28 \% \mathrm{CP}$ ) each with or without added Lys and Met. In studies 2 and 3, 26\% CP and 2.34\% Lys milk replacer treatments were fed to test the concentration of Met $(0.64,0.68$, and $0.72 \%$ Met in study 2 and 0.64 , 0.72 , and $0.80 \%$ Met in study 3 ). In study $4,26 \% \mathrm{CP}$, $2.34 \%$ Lys, and $0.72 \%$ Met milk replacer treatments were fed to test the concentration of Thr $(1.06,1.43$, and $1.80 \%)$. There was a $17 \%$ improvement in average daily gain (ADG) in study 1 from adding Lys and Met that was maximized with $2.34 \%$ Lys. The ADG response to added Met in studies 2 (linear) and 3 (quadratic) were 13 and $7 \%$, respectively, with a plateau at $0.72 \%$ Met. There was no ADG or efficiency response to added Thr in study 4. Formulating $17 \%$ fat, whey-based milk replacers fed at $0.68 \mathrm{~kg} / \mathrm{d}$ to $26 \% \mathrm{CP}, 2.34 \% \mathrm{Lys}$, and $0.72 \%$ Met appeared optimum based on responses of body weight gain, feed efficiency, and serum concentrations of urea nitrogen, while feeding calves more $\mathrm{CP}$ and essential AA did not improved ADG and efficiency. Requirements for calves less than 5 wk old, averaging $48 \mathrm{~kg}$ of BW, consuming $204 \mathrm{~g}$ of $\mathrm{CP} / \mathrm{d}$, and gaining
\end{abstract}

Received August 13, 2007.

Accepted February 26, 2008.

${ }^{1}$ Corresponding author: mhill@akey.com.
$0.46 \mathrm{~kg}$ of BW/d, appeared to be met with $17 \mathrm{~g}$ of Lys, 0.31 Met:Lys ratio, 0.54 Met+Cys:Lys ratio, and a Thr:Lys ratio less than 0.60 .

Key words: calf, amino acid, milk replacer

\section{INTRODUCTION}

The most recent summaries of the AA requirements of calves are Williams and Hewitt (1979), van Weerden and Huisman (1985), Toullec (1989), and Gerrits et al. (1997), all in calves fed milk and no starter. The estimates of Williams and Hewitt (1979) were in 6- to 14wk-old calves growing approximately $0.25 \mathrm{~kg} / \mathrm{d}$. The estimates of van Weerden and Huisman (1985) were in 5- to 7 -wk-old calves growing approximately $0.9 \mathrm{~kg} / \mathrm{d}$. The estimates of Toullec (1989) and Gerrits et al. (1997) were in 2- to 5-mo-old calves growing approximately 1 $\mathrm{kg} / \mathrm{d}$. Diaz et al. (2001) stimulated the notion of feeding herd-replacement dairy calves more than the 450 to $500 \mathrm{~g}$ of milk replacer (MR) powder or approximately $4 \mathrm{~L}$ of milk that is conventional in the US system. They fed calves a $30 \%$ milk CP, $20 \%$ fat MR diet at varying rates up to an maximum consumption of $2.5 \mathrm{~kg}$ of dry milk powder daily with no starter feed or weaning of the calf and observed increased daily gains and feed efficiencies with increased intake of powder. Blome et al. (2003) and Bartlett et al. (2006) have reported increased ADG from feeding increasing amounts of CP and increasing ratios of $\mathrm{CP}$ to energy in calves fed only milk. More recently, Hill et al. (2006a,b, 2007c) have shown that in calves fed starter, feeding a $26 \% \mathrm{CP}, 17 \%$ fat $\mathrm{MR}$ at $0.68 \mathrm{~kg} / \mathrm{d}$ supported more ADG than a $20 \%$ CP, $20 \%$ fat MR fed at $0.45 \mathrm{~kg} / \mathrm{d}$. When the $26 \% \mathrm{CP}$, $17 \%$ fat MR was fed at rates over $1 \mathrm{~kg} / \mathrm{d}, \mathrm{ADG}$ from 3 $\mathrm{d}$ of age through $2 \mathrm{wk}$ postweaning was not increased compared with feeding $0.68 \mathrm{~kg}$ of the MR because of reductions in starter intake (Hill et al., 2007c). Feeding a $20 \% \mathrm{CP}$ MR at rates over $0.45 \mathrm{~kg} / \mathrm{d}$ did not improve ADG in the same way as a higher CP MR did because $\mathrm{CP}$ appeared to be limiting compared with energy (Hill et al., 2006a).

In $20 \% \mathrm{CP}$ MR fed at $0.45 \mathrm{~kg} / \mathrm{d}$, supplementing Lys and Met improved ADG in all whey CP formulas (Hill 
et al., 2007b). Similarly, supplementing Lys, Met, Thr, and Ile has increased ADG in calves fed MR containing milk and soy proteins (Jenkins and Emmons, 1983; Kanjanapruthipong, 1998). Estimates of AA requirements of calves less than 2 mo of age are not available in peer-reviewed form. Additionally, the dairy NRC (2001) does not consider individual AA for calves. Thus, the objective of this series of 4 studies was to estimate the optimal concentrations of Lys, Met, and Thr in MR for calves less than 5 wk of age. Our hypothesis was that Lys, Met, and Thr would be limiting ADG.

\section{MATERIALS AND METHODS}

Holstein bull calves from a single dairy farm were received midday at 2 to $3 \mathrm{~d}$ of age after a 3 -h transit. Their first MR was fed at the p.m. feeding. The day after arrival at approximately noon, the calves were weighed, blood sampled intravenously for serum protein via a refractometer, and assigned to treatment $(\mathrm{d}$ 0 , initial BW). Calf management, health protocols, and measurements of BW, starter intake, fecal scoring, body condition scoring, and serum analysis for albumin, alkaline phosphatase, amylase, creatinine, glucose, total protein, and urea-N was conducted as described in Hill et al. (2007b). In study 3 , blood was sampled on d 12 , 19 , and 23 of the study 90 min after the morning MR feeding. In study 4 , blood was sampled on $\mathrm{d} 9,14$, and 23 of the study 90 min after the morning MR feeding. Calves were housed a curtain-sided, naturally ventilated nursery with no added heat in $1.2 \times 2.4 \mathrm{~m}$ pens bedded with straw. Calves had access to clean, fresh water at all times. All animals were cared for by acceptable practices as described in the Guide for the Care and Use of Agricultural Animals in Agricultural Research and Teaching (FASS, 1999).

In each study, single-source Holstein bull calves initially (d 0) 3 to $4 \mathrm{~d}$ old and $43 \pm 1 \mathrm{~kg}$ of BW were weaned at $28 \mathrm{~d}$ on-study. A $17 \%$ fat MR was fed at $0.681 \mathrm{~kg}$ of powder per day to all calves because this rate has been shown to improve ADG over a conventional $20 \% \mathrm{CP}$, $20 \%$ fat MR while not depressing starter intake or postweaning ADG (Hill et al., 2006b). The MR were manufactured (Akey, Lewisburg, $\mathrm{OH}$ ) by altering the concentrations of whey, whey protein concentrate $(78 \% \mathrm{CP}$ asfed basis), L-Lys, and DL-Met in studies 1, 2, and 3. In study 4 , the MR were manufactured by altering the concentrations of whey, skimmed milk (34\% CP as-fed basis), L-Lys, DL-Met, and L-Thr. The MR were fed at $0.681 \mathrm{~kg}$ of powder per day from d 1 to 28 and divided into 2 equal meals. On d 26 to 28 , calves were only fed $0.340 \mathrm{~kg}$ of $\mathrm{MR}$ powder in the morning to facilitate weaning. The reconstituted MR were $148 \mathrm{~g}$ of powder diluted into a final volume of $1 \mathrm{~L}$ with warm water. All calves consumed the amount of MR offered. Measurements were made through d 56, $28 \mathrm{~d}$ after weaning. Early weaning at $28 \mathrm{~d}$ was used to maximize the contribution of nutrients from MR compared with later weaning when starter intake would have furnished a greater proportion of nutrient intake. An 18\% CP starter (asfed; Hill et al., 2007a) was fed beginning on d 1 . The starter contained $37 \%$ rolled corn, $35 \%$ protein pellet ( $71 \%$ soybean meal, $15 \%$ premix of vitamins, minerals, decoquinate, $12 \%$ wheat middlings, $2 \%$ alfalfa meal), $25 \%$ whole oats, and $3 \%$ molasses. The starter averaged $88.1 \% \mathrm{DM}, 18.0 \% \mathrm{CP}, 3.7 \%$ fat, $0.77 \% \mathrm{Ca}, 0.55 \% \mathrm{P}$, $0.92 \%$ Lys, $0.29 \%$ Met, $0.31 \%$ Cys, $0.68 \%$ Thr, $1.17 \%$ Arg, $3.18 \%$ Glu, $0.47 \%$ His, $0.71 \%$ Iso, $1.44 \%$ Leu, $0.84 \%$ Phe, $0.23 \%$ Trp, $1.65 \%$ Tyr, and $0.81 \%$ Val.

In study 1, 6 MR treatments were fed based on the combination of $3 \mathrm{CP}$ concentrations (24, 26 , and $28 \%$ $\mathrm{CP}$ as-fed basis) each with or without added Lys and Met (Table 1). In a series of studies where, in addition to MR, calves were fed starter and weaned, Hill et al. (2006a,b, 2007c) reported that calves fed $0.68 \mathrm{~kg}$ daily of a $26 \% \mathrm{CP}, 17 \%$ fat MR consistently optimized $\mathrm{ADG}$ compared with greater and lesser concentrations of $\mathrm{CP}$ and fat and feeding rates. However, AA concentrations were not evaluated. The concentrations of Lys and Met in the MR with added Lys and Met were chosen to mimic the ratio of Lys to Met from the 20\% CP MR with added Lys and Met used in the study of Hill et al. (2007b), who based their concentrations of Lys and Met on the 2:1 ratio of Lys:Met+Cys suggested by Toullec (1989) for veal calves over 2 mo of age. Concentrations of Lys and Met in MR without added crystalline Lys and Met were those in the basal ingredients. The Lys and Met were included in the MR to provide a ratio of CP to Lys of 11.1 and a ratio of Lys to Met of 3.25. Study 1 was conducted from April through August with 3 groups of 48 calves (144 total calves) entering the research nursery in consecutive 5 -wk intervals. The average nursery temperature was $18^{\circ} \mathrm{C}$ and ranged from -2 to $32^{\circ} \mathrm{C}$ based on hourly measurements.

In study 2, $3 \mathrm{MR}$ treatments were fed that each contained 26\% CP and 2.34\% Lys because the MR treatment in study 1 that maximized ADG and efficiency had these concentrations. The $3 \mathrm{MR}$ treatments contained graded concentrations of Met $(0.64,0.68$, and $0.72 \%$ Met; Table 2). The high Met treatment was $0.72 \%$ Met because this was the theoretical concentration in the MR from study 1 that maximized ADG (the MR treatment with more Met did not support greater ADG). The intermediate Met concentration was reduced by $0.04 \%$ units based on the 26\% CP MR with added Met from study 1 . The low Met concentration was reduced another $0.04 \%$ units to equally space the theoretical Met concentrations in study 2 . This study was conducted 
Table 1. Assayed nutrient content of milk replacers containing 3 concentrations of $\mathrm{CP}$ with or without added Lys and Met (AA) in study $1^{1}$

\begin{tabular}{|c|c|c|c|c|c|c|}
\hline \multirow[b]{2}{*}{ Nutrient, $\%$ as-fed } & \multicolumn{2}{|c|}{$24 \% \mathrm{CP}$} & \multicolumn{2}{|c|}{$26 \% \mathrm{CP}$} & \multicolumn{2}{|c|}{$28 \% \mathrm{CP}$} \\
\hline & No AA & AA & No AA & $\mathrm{AA}$ & No AA & $\mathrm{AA}$ \\
\hline $\mathrm{DM}$ & 96.1 & 96.1 & 96.1 & 96.1 & 96.1 & 96.1 \\
\hline $\mathrm{CP}$ & 24.3 & 24.2 & 26.1 & 26.1 & 28.0 & 28.0 \\
\hline Fat & 17.1 & 17.0 & 17.2 & 17.0 & 17.2 & 17.3 \\
\hline Ash & 6.5 & 6.5 & 6.4 & 6.4 & 6.4 & 6.3 \\
\hline $\mathrm{Ca}$ & 0.80 & 0.81 & 0.79 & 0.80 & 0.81 & 0.79 \\
\hline $\mathrm{P}$ & 0.61 & 0.61 & 0.62 & 0.61 & 0.62 & 0.62 \\
\hline Lys & 2.06 & 2.21 & 2.20 & 2.39 & 2.41 & 2.59 \\
\hline Met & 0.51 & 0.68 & 0.56 & 0.75 & 0.62 & 0.80 \\
\hline Cys & 0.51 & 0.52 & 0.55 & 0.57 & 0.59 & 0.61 \\
\hline Thr & 1.71 & 1.70 & 1.85 & 1.84 & 1.99 & 2.01 \\
\hline Arg & 0.60 & 0.59 & 0.65 & 0.64 & 0.71 & 0.69 \\
\hline Glu & 4.03 & 4.00 & 4.38 & 4.41 & 4.71 & 4.69 \\
\hline His & 0.45 & 0.44 & 0.49 & 0.50 & 0.53 & 0.53 \\
\hline Ile & 1.39 & 1.35 & 1.51 & 1.48 & 1.60 & 1.59 \\
\hline Leu & 2.40 & 2.42 & 2.62 & 2.62 & 2.78 & 2.82 \\
\hline Phe & 0.78 & 0.76 & 0.83 & 0.83 & 0.89 & 0.86 \\
\hline Trp & 0.40 & 0.43 & 0.44 & 0.45 & 0.47 & 0.49 \\
\hline Tyr & 0.64 & 0.66 & 0.71 & 0.72 & 0.76 & 0.75 \\
\hline Val & 1.37 & 1.40 & 1.51 & 1.53 & 1.64 & 1.62 \\
\hline Calculated DE, ${ }^{2} \mathrm{Mcal} / \mathrm{kg}$ & 4.88 & 4.88 & 4.93 & 4.93 & 4.97 & 4.97 \\
\hline
\end{tabular}

${ }^{1}$ Milk replacers (MR) with added Lys and Met were formulated to $2.16 \%$ Lys and $0.66 \%$ Met in the $24 \%$ CP MR, 2.34\% Lys and $0.72 \%$ Met in the 26\% CP MR, and 2.52\% Lys and 0.78\% Met in the 28\% CP MR.

${ }^{2}$ Digestible energy; calculated using NRC (2001) equations.

September through November with 48 total calves. The average nursery temperature was $13^{\circ} \mathrm{C}$ and ranged from -5 to $32^{\circ} \mathrm{C}$ based on hourly measurements.

Because no plateau in ADG was observed in study 2, study 3 was designed using a greater maximum concen- tration of Met (0.64, 0.72, and $0.80 \%$ Met; Table 3), to further evaluate Met concentration in the MR. The 3 MR treatments fed each contained $26 \% \mathrm{CP}$ and $2.34 \%$ Lys. This study was conducted September through November with 48 total calves. The average nursery tem-
Table 2. Assayed nutrient concentration of milk replacers ${ }^{1}$ containing 3 concentrations of Met in study 2

\begin{tabular}{lccc}
\hline \multirow{2}{*}{$\begin{array}{l}\text { Nutrient, } \\
\text { \% as-fed }\end{array}$} & \multicolumn{3}{c}{ Formulated Met concentration, \% } \\
\cline { 2 - 4 } DM & 0.64 & 0.68 & 0.72 \\
CP & 96.4 & 96.4 & 96.3 \\
Fat & 25.9 & 25.8 & 25.9 \\
Ash & 17.7 & 17.9 & 18.0 \\
Ca & 6.3 & 6.4 & 6.4 \\
P & 0.81 & 0.79 & 0.80 \\
Lys & 0.63 & 0.61 & 0.62 \\
Met & 2.35 & 2.36 & 2.37 \\
Cys & 0.66 & 0.69 & 0.74 \\
Thr & 0.54 & 0.55 & 0.54 \\
Arg & 1.85 & 1.83 & 1.84 \\
Glu & 0.65 & 0.64 & 0.67 \\
His & 4.38 & 4.31 & 4.43 \\
Ile & 0.49 & 0.50 & 0.50 \\
Leu & 1.51 & 1.49 & 1.50 \\
Phe & 2.62 & 2.65 & 2.66 \\
Trp & 0.83 & 0.81 & 0.84 \\
Tyr & 0.44 & 0.43 & 0.44 \\
Val & 0.70 & 0.74 & 0.72 \\
\hline
\end{tabular}

${ }^{1}$ Each was 4.93 Mcal of digestible energy/kg (as-fed) calculated using NRC (2001) equations.
Table 3. Assayed nutrient concentration of milk replacers ${ }^{1}$ containing 3 concentrations of Met in study 3

\begin{tabular}{lccc}
\hline & \multicolumn{3}{c}{ Formulated Met concentration, \% } \\
\cline { 2 - 4 } Nutrient, & 0.64 & 0.72 & 0.80 \\
\hline DM-fed & 95.9 & 95.9 & 95.9 \\
CP & 26.2 & 26.0 & 26.3 \\
Fat & 17.1 & 17.2 & 17.1 \\
Ash & 6.3 & 6.4 & 6.2 \\
Ca & 0.78 & 0.79 & 0.79 \\
P & 0.60 & 0.62 & 0.61 \\
Lys & 2.30 & 2.28 & 2.28 \\
Met & 0.63 & 0.71 & 0.80 \\
Cys & 0.56 & 0.56 & 0.55 \\
Thr & 1.84 & 1.83 & 1.85 \\
Arg & 0.69 & 0.70 & 0.67 \\
Glu & 4.44 & 4.49 & 4.35 \\
His & 0.48 & 0.49 & 0.48 \\
Ile & 1.48 & 1.51 & 1.47 \\
Leu & 2.65 & 2.68 & 2.70 \\
Phe & 0.80 & 0.79 & 0.83 \\
Trp & 0.43 & 0.43 & 0.43 \\
Tyr & 0.73 & 0.71 & 0.70 \\
Val & 1.50 & 1.51 & 1.53 \\
\hline
\end{tabular}

${ }^{1}$ Each was $4.93 \mathrm{Mcal}$ of digestible energy/kg (as-fed) calculated using NRC (2001) equations. 
Table 4. Assayed nutrient concentration of milk replacers ${ }^{1}$ containing 3 concentrations of Thr in study 4

\begin{tabular}{lccc}
\hline & \multicolumn{3}{c}{ Formulated Thr concentration, \% } \\
\cline { 2 - 4 } Nutrient, & 1.06 & 1.43 & 1.80 \\
\hline DM & 96.8 & 97.0 & 96.7 \\
CP & 26.5 & 26.5 & 26.6 \\
Fat & 17.7 & 17.6 & 17.7 \\
Ash & 6.6 & 6.7 & 6.5 \\
Ca & 0.82 & 0.81 & 0.80 \\
P & 0.59 & 0.62 & 0.62 \\
Lys & 2.32 & 2.29 & 2.31 \\
Met & 0.73 & 0.71 & 0.73 \\
Cys & 0.26 & 0.28 & 0.28 \\
Thr & 1.06 & 1.48 & 1.82 \\
Arg & 0.88 & 0.90 & 0.87 \\
Glu & 5.17 & 5.02 & 0.51 \\
His & 0.66 & 0.69 & 0.68 \\
Ile & 1.41 & 1.40 & 1.38 \\
Leu & 2.53 & 2.41 & 2.44 \\
Phe & 1.20 & 1.18 & 1.22 \\
Trp & 0.39 & 0.40 & 0.41 \\
Tyr & 1.17 & 1.21 & 1.15 \\
Val & 1.70 & 1.79 & 1.73 \\
\hline
\end{tabular}

${ }^{1}$ Each was $4.93 \mathrm{Mcal}$ of digestible energy/kg (as-fed) calculated using NRC (2001) equations.

perature was $12^{\circ} \mathrm{C}$ and ranged from -4 to $32^{\circ} \mathrm{C}$ based on hourly measurements.

In study 4, 3 MR treatments were fed that each contained 26\% CP, 2.34\% Lys, and 0.72\% Met (Table 4). These concentrations were based on the concentration used in studies 1,2 , and 3 that achieved the greatest $\mathrm{ADG}$. The $3 \mathrm{MR}$ treatments evaluated graded concentrations of Thr (1.06, 1.43, and 1.80\% Thr). Whey protein from whey and whey protein concentrate was used as the base source of milk protein in studies 1,2, and 3 , resulting in approximately $1.8 \% \mathrm{Thr}$ and a Lys:Thr ratio of 0.77 . This exceeds the ratio of Lys to Thr calculated from Williams and Hewitt (1979), van Weerden and Huisman (1985), Toullec (1989), and Gerrits et al. (1997) of 0.60 or less. Whey protein is high in Thr relative to skim milk powder. Thus, study 4 was designed using skim milk powder instead of whey protein concentrate to lower the basal Thr in an attempt to better estimate a Thr requirement. Calves in study 4 were all fed the $1.06 \%$ Thr MR for the first $9 \mathrm{~d}$, then from $\mathrm{d} 10$ to 28 fed their randomly assigned MR treatment. This initial 9-d period was used to establish a baseline measurement from which to calculate any potential change in selected serum metabolites. This study was conducted November through January with 48 total calves. The average nursery temperature was $-6^{\circ} \mathrm{C}$ and ranged from -8 to $13^{\circ} \mathrm{C}$ based on hourly measurements.

Approximately $110 \%$ of the estimated feeds needed for each study were manufactured at one time. Samples were collected from every other bag $(22.7 \mathrm{~kg})$ of feed at the time of manufacture. Composites were analyzed
(AOAC, 2000) before the animal phase of the studies for DM (oven method; method 930.15), CP (Kjeldahl method; method 988.05), fat (alkaline treatment with Röse-Gottlieb method; method 932.06), ash (muffle furnace method; method 923.03), Ca, P (NIR method; method 989.03), and AA by HPLC. Amino acids were determined after acid hydrolysis (method $982.30 \mathrm{E}[\mathrm{a}]$; AOAC, 2000). Total sulfur AA were determined after performic acid oxidation and acid hydrolysis (method 982.30 E[b]; AOAC, 2000). Tryptophan content was determined after alkaline hydrolysis (method $982.30 \mathrm{E}[\mathrm{c}]$; AOAC, 2000).

Data from each study were analyzed separately as completely randomized block designs using the GLM procedure of SAS (version 8, SAS Institute Inc., Cary, NC). Single estimates for the growth measures of ADG, average starter intake and feed efficiency, change in BCS and hip width, average fecal score, total days requiring medical treatment, and total days when fecal score exceeded 2 were calculated for the 28 -d milk-fed period and 28-d postweaning period of each study and used in the analysis. The statistical model included terms for treatment, calf, and experimental error. Means for treatment's concentration of CP in study 1 and the concentration of AA tested in studies 2, 3, and 4 were separated using linear and quadratic contrast statements. Serum metabolite data from study 3 were analyzed using a mixed model as repeated measures. The model included terms for treatment, day, and the interaction of treatment and day. Calf nested within treatment was included as a random effect that was used to test the main effect of treatment. Day was modeled as a repeated measurement using an autoregressive type 1 covariance structure. Similar procedures were used to analyze serum metabolite data from study 4 with the following exceptions. Because all calves were fed a common diet for the first $9 \mathrm{~d}$ of the study, serum metabolite measures from $d 9$ were included as a covariate when analyzing data from study 4. Data reported are least squares means for the experimental unit (calf) in all studies.

\section{RESULTS}

No calves died or were removed from the studies. In each study, there were no differences $(P>0.05)$ in initial BW, serum protein, hip widths, or BCS. Change in hip width and BCS, abnormal fecal score days, medical days, and average fecal score did not differ $(P>0.05)$ among treatments in any study.

Assayed nutrients for the MR fed in study 1 are reported in Table 1. In study 1, intake of CP, apparent digestible protein (ADP), Lys, Met, and Thr increased linearly $(P<0.05)$ with increasing concentration of $\mathrm{CP}$ 
Table 5. Effect of 3 concentrations of $\mathrm{CP}$ with or without added Lys and Met (AA) on ADG, intake, and efficiency of calves for $28 \mathrm{~d}$ in study 1

\begin{tabular}{|c|c|c|c|c|c|c|c|c|}
\hline \multirow[b]{2}{*}{ Item } & \multicolumn{2}{|c|}{$24 \% \mathrm{CP}$} & \multicolumn{2}{|c|}{$26 \% \mathrm{CP}$} & \multicolumn{2}{|c|}{$28 \% \mathrm{CP}$} & \multicolumn{2}{|c|}{ SEM } \\
\hline & No AA & $\mathrm{AA}$ & No AA & AA & No AA & $\mathrm{AA}$ & $\mathrm{CP}$ & $\mathrm{AA}$ \\
\hline Calves, $\mathrm{n}$ & 24 & 24 & 24 & 24 & 24 & 24 & - & - \\
\hline Initial serum protein, $\mathrm{mg} / \mathrm{dL}$ & 5.0 & 5.2 & 5.0 & 5.3 & 5.2 & 5.2 & 0.2 & 0.1 \\
\hline Initial weight, kg & 42.5 & 42.4 & 43.5 & 42.0 & 42.5 & 42.7 & 0.8 & 0.7 \\
\hline $\mathrm{ADG},{ }^{1,2,3} \mathrm{~kg} / \mathrm{d}$ & 0.376 & 0.446 & 0.415 & 0.484 & 0.447 & 0.468 & 0.020 & 0.018 \\
\hline Starter intake, $\mathrm{kg} / \mathrm{d}$ & 0.143 & 0.127 & 0.143 & 0.153 & 0.152 & 0.135 & 0.017 & 0.016 \\
\hline Milk replacer intake, $\mathrm{kg} / \mathrm{d}$ & 0.645 & 0.645 & 0.645 & 0.645 & 0.645 & 0.645 & - & - \\
\hline Feed efficiency ${ }^{1,2,3,4}$ & 0.472 & 0.580 & 0.523 & 0.608 & 0.556 & 0.596 & 0.019 & 0.016 \\
\hline Digestible energy intake, Mcal/d & 3.59 & 3.54 & 3.62 & 3.65 & 3.68 & 3.62 & 0.51 & 0.48 \\
\hline CP intake,${ }^{1} \mathrm{~kg} / \mathrm{d}$ & 0.182 & 0.179 & 0.194 & 0.196 & 0.208 & 0.205 & 0.022 & 0.020 \\
\hline $\mathrm{ADP}^{5}$ intake,${ }^{1} \mathrm{~g} / \mathrm{d}$ & 0.165 & 0.162 & 0.176 & 0.177 & 0.189 & 0.186 & 0.020 & 0.018 \\
\hline Lys intake, ${ }^{1,2} \mathrm{~g} / \mathrm{d}$ & 14.6 & 15.4 & 15.5 & 16.8 & 16.9 & 17.9 & 1.9 & 1.6 \\
\hline Met intake,${ }^{1,2} \mathrm{~g} / \mathrm{d}$ & 3.7 & 4.8 & 4.1 & 5.3 & 4.5 & 5.6 & 0.6 & 0.5 \\
\hline Thr intake, ${ }^{1} \mathrm{~g} / \mathrm{d}$ & 12.7 & 12.5 & 13.6 & 13.7 & 14.6 & 14.5 & 1.6 & 1.4 \\
\hline Energy-allowable ADG ${ }^{6} \mathrm{~kg} / \mathrm{d}$ & 0.55 & 0.54 & 0.56 & 0.57 & 0.57 & 0.57 & - & - \\
\hline Protein-allowable ADG ${ }^{6} \mathrm{~kg} / \mathrm{d}$ & 0.59 & 0.58 & 0.64 & 0.65 & 0.70 & 0.70 & - & - \\
\hline
\end{tabular}

${ }^{1}$ Increased linearly with $\mathrm{CP}(P<0.05)$.

${ }^{2}$ Differed with AA supplementation $(\mathrm{P}<0.05)$.

${ }^{3} \mathrm{CP}$ and AA interacted $(P<0.05)$.

${ }^{4}$ Gain divided by milk replacer (MR) plus starter intake.

${ }^{5}$ Apparent digestible protein intake $(0.93 \times \mathrm{MR} \mathrm{CP}$ and $0.75 \times$ starter $\mathrm{CP})$.

${ }^{6}$ Predicted ME- and ADP-allowable gain using NRC (2001) submodel.

in the MR (Table 5). Calf ADG and efficiency increased linearly $(P<0.05)$ with increasing concentration of $\mathrm{CP}$ in the MR. Intake of Lys, Met, and Thr was greater $(P$ $<0.05)$ in calves fed the MR with added Lys and Met than in calves fed the MR without added Lys and Met. There was an interaction of concentration of $\mathrm{CP}$ and
AA $(P<0.05)$ for ADG and efficiency with calves fed the $28 \%$ CP MR with added Lys and Met not increasing in ADG and efficiency compared with calves fed the $28 \%$ CP MR without added Lys and Met. However, the main effect of added AA was also significant $(P<0.05)$ because calves fed MR at lower $\mathrm{CP}$ concentrations with

Table 6. Effect of 3 concentrations of Met on ADG, intake, and efficiency of calves for $28 \mathrm{~d}$ in study 2

\begin{tabular}{|c|c|c|c|c|}
\hline \multirow[b]{2}{*}{ Measurement } & \multicolumn{3}{|c|}{ Formulated Met concentrations, $\%$} & \multirow[b]{2}{*}{ SEM } \\
\hline & 0.64 & 0.68 & 0.72 & \\
\hline Calves, $\mathrm{n}$ & 16 & 16 & 16 & - \\
\hline Initial serum protein,${ }^{1} \mathrm{mg} / \mathrm{dL}$ & 5.1 & 4.7 & 5.1 & 0.2 \\
\hline Initial wt, kg & 42.7 & 41.9 & 43.5 & 1.0 \\
\hline $\mathrm{ADG},^{2} \mathrm{~kg} / \mathrm{d}$ & 0.418 & 0.426 & 0.473 & 0.03 \\
\hline Starter intake, ${ }^{3} \mathrm{~kg} / \mathrm{d}$ & 0.135 & 0.113 & 0.194 & 0.016 \\
\hline Milk replacer intake, $\mathrm{kg} / \mathrm{d}$ & 0.645 & 0.645 & 0.645 & - \\
\hline Feed efficiency ${ }^{4}$ & 0.534 & 0.557 & 0.565 & 0.036 \\
\hline Digestibile energy intake, Mcal/d & 3.60 & 3.53 & 3.78 & 0.49 \\
\hline $\mathrm{CP}$ intake, $\mathrm{kg} / \mathrm{d}$ & 0.191 & 0.187 & 0.202 & 0.019 \\
\hline ADP intake, ${ }^{5} \mathrm{~g} / \mathrm{d}$ & 0.174 & 0.170 & 0.181 & 0.017 \\
\hline Lys intake, $\mathrm{g} / \mathrm{d}$ & 16.4 & 16.3 & 17.1 & 0.2 \\
\hline Met intake, ${ }^{6} \mathrm{~g} / \mathrm{d}$ & 4.6 & 4.8 & 5.4 & 0.4 \\
\hline Thr intake, g/d & 13.5 & 13.1 & 14.1 & 1.5 \\
\hline Energy allowable ADG,${ }^{7} \mathrm{~kg} / \mathrm{d}$ & 0.49 & 0.47 & 0.53 & - \\
\hline Protein allowable $\mathrm{ADG},{ }^{7} \mathrm{~kg} / \mathrm{d}$ & 0.64 & 0.63 & 0.66 & - \\
\hline
\end{tabular}

${ }^{1}$ Quadratic relationship (trend) to Met $(P<0.06)$.

${ }^{2}$ Linear relationship to Met $(P<0.02)$.

${ }^{3}$ Quadratic relationship to Met $(P<0.012)$.

${ }^{4}$ Gain divided by milk replacer (MR) plus starter intake.

${ }^{5}$ Apparent digestible protein intake $(0.93 \times \mathrm{MR} \mathrm{CP}$ and $0.75 \times$ starter $\mathrm{CP})$.

${ }^{6}$ Linear relationship to $\operatorname{Met}(P<0.05)$.

${ }^{7}$ Predicted ME and ADP allowable gain using NRC (2001) submodel. 
HILL ET AL.

Table 7. Effect of 3 concentrations of Met on ADG, intake, and efficiency of calves for $28 \mathrm{~d}$ in study 3

\begin{tabular}{lcccc}
\hline & \multicolumn{3}{c}{ Formulated Met concentration, \% } & \\
\cline { 2 - 4 } Item & 0.64 & 0.72 & 0.80 & SEM \\
\hline Calves, n & 14 & 14 & 14 & - \\
Initial serum protein, mg/dL & 5.0 & 5.2 & 5.1 & 0.18 \\
Initial weight, kg & 42.0 & 42.2 & 42.4 & 1.4 \\
ADG, ${ }^{1} \mathrm{~kg} / \mathrm{d}$ & 0.423 & 0.456 & 0.442 & 0.009 \\
Starter intake, kg/d & 0.158 & 0.160 & 0.181 & 0.025 \\
Milk replacer intake, kg/d & 0.645 & 0.645 & 0.645 & - \\
Feed efficiency,3 & 0.529 & 0.569 & 0.540 & 0.018 \\
DE intake, Mcal/d & 3.67 & 3.68 & 3.74 & 0.023 \\
CP intake, kg/d & 0.197 & 0.197 & 0.202 & 0.021 \\
ADP intake, ${ }^{4}$ g/d & 0.180 & 0.178 & 0.182 & 0.2 \\
Lys intake, g/d & 16.3 & 16.2 & 16.4 & 1.6 \\
Met intake, ${ }^{5}$ g/d & 4.6 & 5.1 & 5.7 & - \\
Thr intake, g/d & 13.7 & 13.7 & 14.1 & - \\
Energy-allowable ADG, ${ }^{6} \mathrm{~kg} / \mathrm{d}$ & 0.50 & 0.50 & 0.52 & 0.66 \\
Protein-allowable ADG, ${ }^{6} \mathrm{~kg} / \mathrm{d}$ & 0.65 & 0.65 & & \\
\hline
\end{tabular}

${ }^{1}$ Quadratic relationship to Met $(P<0.01)$.

${ }^{2}$ Gain divided by milk replacer (MR) plus starter intake.

${ }^{3}$ Quadratic relationship to Met $(P<0.05)$.

${ }^{4}$ Apparent digestible protein intake $(0.93 \times \mathrm{MR} \mathrm{CP}$ and $0.75 \times$ starter $\mathrm{CP})$.

${ }^{5}$ Linear relationship to Met $(P<0.05)$.

${ }^{6}$ Predicted ME and ADP allowable gain using NRC (2001) submodel.

added AA had greater ADG and efficiency than calves fed the MR without added Lys and Met. In study 1, the MR with $26 \% \mathrm{CP}$ and added Lys (2.34\%) and Met $(0.72 \%)$ supported the greatest ADG. The difference in ADG between calves fed the $26 \%$ CP MR with and without Lys and Met was 16\%. The calves fed the MR with $26 \% \mathrm{CP}$ and added Lys and Met had $8 \%$ greater ADG than the calves fed the $28 \% \mathrm{CP}$ MR without added no Lys and Met. The $28-\mathrm{d}$ postweaning ADG $(0.87 \mathrm{~kg} / \mathrm{d})$, starter intake $(1.90 \mathrm{~kg} / \mathrm{d})$, and other performance measures of the calves did not differ $(P>0.05)$ among treatments.

Assayed nutrients for the MR fed in study 2 are reported in Table 2. In study 2, Met intake and ADG increased linearly $(P<0.05)$ and starter intake responded quadratically $(P<0.05)$ to concentration of Met in the MR (Table 6). Starter intake decreased at the first addition of Met $(0.68 \%)$ but was greatest for calves fed the high $(0.72 \%)$ concentration of Met. The 28-d postweaning ADG $(0.73 \mathrm{~kg} / \mathrm{d})$, starter intake $(1.83 \mathrm{~kg} /$ d), and other performance measures of the calves did not differ $(P>0.05)$ among treatments.

Assayed nutrients for the MR fed in study 3 are reported in Table 3. In study 3, ADG and feed efficiency responded quadratically $(P<0.05)$ with increasing concentrations of Met in the MR (Table 7). Maximum response was achieved with the intermediate concentration of $0.72 \%$ Met and there was no increase in $\mathrm{ADG}$ or efficiency with the high concentration of $0.80 \%$ Met. Serum concentrations of urea nitrogen and creatinine responded in a quadratic manner $(P<0.05)$ to Met concentration in the MR (Table 8). Calves fed the low concentration of $0.64 \%$ Met had the greatest serum concentration of urea nitrogen, indicating inefficient use of dietary $\mathrm{N}$, and lowest concentration of creatinine, indicating less muscle mass, relative to the greater concentrations of Met. Other serum metabolites measured did not differ $(P>0.05)$. The 28 -d postweaning ADG $(0.76 \mathrm{~kg} / \mathrm{d})$, starter intake $(1.88 \mathrm{~kg} / \mathrm{d})$, and other performance measures of the calves did not differ $(P>0.05)$ among treatments.

Assayed nutrients for the MR fed in study 4 are reported in Table 4. In study 4, Thr intake increased linearly $(P<0.05)$ with Thr concentration of the MR (Table 9). There were no differences $(P>0.05)$ for ADG, starter intake, or efficiency relative to Thr concentration of the MR. Serum metabolites are reported in Table 10. Serum urea nitrogen concentrations responded quadratically $(P<0.01)$ to concentration of Thr in the MR. Calves fed MR with $1.80 \% \mathrm{Thr}$ had a greater concentration of serum urea nitrogen than calves fed the MR with 1.06 and $1.43 \%$ Thr. Serum alkaline phosphatase responded quadratically $(P<0.05)$ to concentration of Thr in the MR with calves fed the MR with $1.43 \% \mathrm{Thr}$ having the greatest increase. Other serum metabolites measured did not differ $(P>0.1)$. The 28 -d postweaning ADG $(0.88 \mathrm{~kg} / \mathrm{d})$, starter intake $(2.28 \mathrm{~kg} / \mathrm{d})$, and other performance measures of the calves did not differ $(P>$ 0.05 ) among treatments.

\section{DISCUSSION}

In study $1,2.34 \%$ Lys ( $0.48 \mathrm{~g}$ of Lys/Mcal of digestible energy, DE) in the MR maximized ADG and efficiency. 
Table 8. Effect of 3 concentrations of Met on selected serum constituents of calves in study 3

\begin{tabular}{lcccc}
\hline & \multicolumn{3}{c}{ Formulated Met concentration, \% } & SEM \\
\cline { 2 - 4 } Item & 0.64 & 0.72 & 0.80 & 0.14 \\
\hline Urea nitrogen, ${ }^{1}$ mmol/L & 4.2 & 2.6 & 2.5 & 2.8 \\
Creatinine, ${ }^{2} \mu \mathrm{mol} / \mathrm{L}$ & 82.2 & 93.5 & 88.0 & 20 \\
Alkaline phosphatase, U/L & 223 & 240 & 235 & 0.36 \\
Albumin, g/L & 13.6 & 13.6 & 13.8 & 0.79 \\
Total protein, g/L & 51.7 & 51.7 & 5.9 & 0.20 \\
Glucose, mmol/L & 5.2 & 5.3 & & \\
\hline
\end{tabular}

${ }^{1}$ Quadratic relationship to Met $(P<0.01)$.

${ }^{2}$ Quadratic relationship to Met $(P<0.05)$.

This calculated to $4.6 \mathrm{~g}$ of Lys/Mcal of DE consumed from both the MR and starter. In study 2, a maximum ADG response to Met was not achieved. One anomaly of this study was that starter intake responded quadratically to Met in the MR with the $0.68 \%$ Met (intermediate) treatment having a lower intake. No other study had a change in starter intake because of treatment. If starter intake of this intermediate Met treatment in study 2 had been the average of the low and high Met treatments, this added starter intake would have increased ADG to approximately $0.46 \mathrm{~kg} / \mathrm{d}$ (per equations of NRC, 2001) perhaps resulting in a quadratic relationship of ADG to Met in the MR rather than the linear relationship observed. The ADG response would have then approached a plateau, indicating that $0.68 \%$ Met was near the optimum. In study $3,0.72 \%$ Met or a Met to Lys ratio of 0.31 appeared near optimum.

In study $4, \mathrm{ADG}$, starter intake, and efficiency did not change with Thr concentration, which could indi- cate that $1.06 \% \mathrm{Thr}$ or a Thr to Lys ratio of 0.45 is adequate. However, the change in serum alkaline phosphatase might also indicate that the low concentration of $1.06 \% \mathrm{Thr}$ was deficient, supporting less bone formation, and that the intermediate concentration of $1.43 \%$ $\mathrm{Thr}(0.60 \mathrm{Thr}$ to Lys ratio) was adequate. The $1.43 \% \mathrm{Thr}$ concentration was selected to be approximately equal to the 0.6 ratio of Thr to Lys from both Williams and Hewitt (1979) and Toullec (1989). The Cys concentration of skim milk is low relative to whey protein concentrate. The MR in study 4 had approximately $0.27 \%$ Cys whereas those in studies 1,2 , and 3 had approximately $0.55 \%$ Cys. The concentrations of $2.34 \%$ Lys, $0.72 \%$ Met, and $0.55 \%$ Cys yield a Met+Cys to Lys ratio of 0.54 , which is greater than estimates from Williams and Hewitt (1979), van Weerden and Huisman (1985), Toullec (1989), and Gerrits et al. (1997), which ranged from 0.41 to 0.51 . However, the Met+Cys to Lys ratio in study 4 was approximately 0.42 , similar to the estimate of

Table 9. Effect of 3 concentrations of Thr on ADG, intake, and efficiency of calves for $28 \mathrm{~d}$ in study 4

\begin{tabular}{lcccc}
\hline & \multicolumn{3}{c}{ Formulated Thr concentration, \% } & \\
\cline { 2 - 4 } Item & 1.06 & 1.43 & 1.80 & SEM $^{1}$ \\
\hline Calves, n & 16 & 16 & 16 & - \\
Initial serum protein, mg/dL & 5.0 & 5.0 & 4.9 & 0.2 \\
Initial weight, kg & 45.1 & 44.9 & 45.9 & 1.5 \\
ADG, kg/d & 0.569 & 0.576 & 0.563 & 0.043 \\
Starter intake, kg/d & 0.284 & 0.286 & 0.272 & 0.034 \\
Milk replacer intake, kg/d & 0.638 & 0.638 & 0.638 & - \\
Feed efficiency ${ }^{2}$ & 0.614 & 0.620 & 0.616 & 0.031 \\
Digestible energy intake, Mcal/d & 4.03 & 4.03 & 3.99 & 0.54 \\
CP intake, kg/d & 0.220 & 0.221 & 0.219 & 0.023 \\
ADP intake, ${ }^{3}$ g/d & 0.196 & 0.196 & 0.194 & 0.019 \\
Lys intake, g/d & 17.4 & 17.2 & 17.2 & 0.2 \\
Met intake, g/d & 5.5 & 5.4 & 5.5 & 1.6 \\
Thr intake, ${ }^{4}$ g/d & 10.1 & 12.8 & 14.8 & - \\
Energy-allowable ADG, ${ }^{5} \mathrm{~kg} / \mathrm{d}$ & 0.29 & 0.30 & 0.28 & - \\
Protein-allowable ADG, ${ }^{5} \mathrm{~kg} / \mathrm{d}$ & 0.71 & 0.71 & 0.70 & \\
\hline
\end{tabular}

${ }^{1}$ No differences among Thr concentrations $(P>0.05)$.

${ }^{2}$ Gain divided by milk replacer (MR) plus starter intake.

${ }^{3}$ Apparent digestible protein intake $(0.93 \times \mathrm{MR} \mathrm{CP}$ and $0.75 \times$ starter $\mathrm{CP})$.

${ }^{4}$ Linear relationship to Thr $(P<0.05)$.

${ }^{5}$ Predicted ME and ADP allowable gain using NRC (2001) submodel. 
HILL ET AL.

Table 10. Effect of 3 concentrations of Thr on selected serum constituents of calves in study 4

\begin{tabular}{lcccc}
\hline & \multicolumn{3}{c}{ Formulated Thr concentration, \% } & \\
\cline { 2 - 4 } Item & 1.06 & 1.43 & 1.80 & SEM \\
\hline Urea nitrogen, ${ }^{1}$ mmol/L & 3.2 & 3.1 & 3.8 & 0.14 \\
Creatinine, $\mu$ mol/L & 81.2 & 83.6 & 79.7 & 3.2 \\
Alkaline phosphatase ${ }^{1}{ }^{1} \mathrm{U} / \mathrm{L}$ & 116 & 191 & 173 & 7.1 \\
Albumin, g/L & 13.8 & 13.9 & 13.6 & 0.23 \\
Total protein, g/L & 58.9 & 58.4 & 57.3 & 0.62 \\
Glucose, mmol/L & 6.0 & 5.6 & 5.7 & 0.26 \\
\hline
\end{tabular}

${ }^{1}$ Quadratic relationship to Thr $(P<0.01)$.

0.41 from van Weerden and Huisman (1985). If the Met+Cys to Lys ratio was a limiting nutrient, it may not have allowed for a proper evaluation of Thr concentrations. Another difference in study 4 and the previous studies was the low temperature of $-6^{\circ} \mathrm{C}$. This low temperature did not result in lower ADG compared with the previous studies. In fact, ADG and starter intake of calves in study 4 appeared greater than in the other studies. Cold is expected to increase intake and to increase maintenance energy requirements and not affect ADP requirements (NRC, 2001). Predicted energy-allowable ADG were approximately $0.30 \mathrm{~kg} / \mathrm{d}$ for calves in study 4 or approximately half of actual ADG. A microenvironment considerably warmer than $-6^{\circ} \mathrm{C}$ within the straw bedding of the calves might have reduced any cold stress of the calves (Hill et al., 2007d), and temperature should not have affected the results of the Thr treatments.

The optimum concentrations of Lys (2.34\%) and Met $(0.72 \%)$ and the average concentration of AA, their daily intake from MR, and their ratio to Lys from studies 1, 2 , and 3 where whey-based MR were fed are shown in Table 11. Similar data from study 4, in which the MR with skim milk were fed using $1.84 \% \mathrm{Thr}$, are also shown in Table 11. Also, the calculated AA ratios to Lys from Williams and Hewitt (1979), van Weerden and Huisman (1985), Toullec (1989), and Gerrits et al. (1997) are listed in Table 11. For studies 1, 2, and 3, the ratios to Lys for His (0.21), Arg (0.28), and Phe+Tyr (0.66) were lower than ratios to Lys calculated from Williams and Hewitt (1979), van Weerden and Huisman (1985), Toullec (1989), and Gerrits et al. (1997). The ratios to Lys for Val (0.64) and Ile (0.64) are lower than ratios to Lys calculated from Toullec (1989) but greater than values from Williams and Hewitt (1979), van Weerden and Huisman (1985), and Gerrits et al. (1997). For study 4, the ratios to Lys for Arg (0.38), His (0.29), Ile (0.60), Leu (1.05), and Met+Cys (0.42) were lower than some of the ratios calculated from the literature. The AA ratios determined in studies 1,2 , and 3 using whey-based MR and in study 4 using skim-milkbased MR were different from the literature in which skim-milk-based MR were fed. We are not aware of attempts to measure a response to supplementing His, Arg, Phe, Tyr, Val, Leu, and Ile in whey-based calf $\mathrm{MR}$, and these AA are presently not commercially cost effective as synthetic AA.

Starter nutrients would be subjected to some degradation in the immature rumen and should have a lower postruminal digestibility than milk protein. Yet by design, calves were weaned early to minimize the contribution of starter to nutrient intake during the 28-d preweaning period. Starter intake averaged $0.15 \mathrm{~kg}$ daily in studies 1, 2, and 3. Using this intake and the average $\mathrm{CP}$ and $\mathrm{AA}$ concentrations of the starters, the starters only contributed approximately $13 \%$ of CP (27 g) and $8 \%$ of Lys $(1.4 \mathrm{~g})$, Met $(0.4 \mathrm{~g})$, and Thr $(0.5 \mathrm{~g})$ consumed by the calves each day. Total daily intakes were approximately $204 \mathrm{~g}$ of CP, $17 \mathrm{~g}$ of Lys, $5 \mathrm{~g}$ of Met, $13 \mathrm{~g}$ of Thr, and $9 \mathrm{~g}$ of Met+Cys in calves gaining approximately $0.46 \mathrm{~kg} / \mathrm{d}$ and fed the $26 \% \mathrm{CP}$ with synthetic Lys and Met. In study 1, calves fed the 28\% CP MR with synthetic Lys and Met consumed 9 to $11 \%$ more Lys, Met, Cys, and Thr and 4 to $12 \%$ more of the other AA than calves fed the $26 \%$ CP MR with synthetic Lys and Met. All of the AA were approximately adequate in the $26 \%$ CP MR with synthetic Lys and Met, because calves fed the 26 and $28 \%$ CP MR with synthetic Lys and Met had similar ADG (0.484 and 0.468 $\mathrm{kg} / \mathrm{d})$ and efficiency (0.608 and 0.596).

The daily intakes of $204 \mathrm{~g}$ of CP, $17 \mathrm{~g}$ of Lys, $5 \mathrm{~g}$ of Met, $13 \mathrm{~g}$ of Thr, and $9 \mathrm{~g}$ of Met+Cys in 48-kg calves gaining $0.46 \mathrm{~kg}$ of $\mathrm{BW} / \mathrm{d}$ in the current trials were greater than estimates of Gerrits et al. (1997) in calves gaining $0.932 \mathrm{~kg} / \mathrm{d}$, implying less efficient use of nutrients in the current studies. Gerrits et al. (1997) estimated requirements of $16.3 \mathrm{~g}$ of Lys/d, $4.2 \mathrm{~g}$ of Met/d, $10.8 \mathrm{~g}$ of Thr/d, and $7.6 \mathrm{~g}$ of Met+Cys/d in $90-\mathrm{kg}$ veal calves consuming $263 \mathrm{~g}$ of $\mathrm{CP} / \mathrm{d}$. The estimates of Gerrits et al. (1997) for these AA increased $11 \%$ for $90-\mathrm{kg}$ calves consuming $352 \mathrm{~g}$ of CP/d and gaining $1.056 \mathrm{~kg} /$ d. Williams and Hewitt (1979) estimated that 6-to 14wk-old, 50- to 58-kg BW calves gaining $0.25 \mathrm{~kg} / \mathrm{d}$ required $7.8 \mathrm{~g}$ of Lys. The housing of calves in the current 
Table 11. Amino acid concentrations in milk replacer (MR), intake from MR, and ratio to Lys in the current studies (studies 1 , 2, and 3 were whey-based diets; study 4 was a diet based on skim milk protein) and ratio to Lys in selected literature studies ${ }^{1}$

\begin{tabular}{|c|c|c|c|c|c|c|c|c|c|c|}
\hline Item & \multicolumn{3}{|c|}{ Studies 1,2 , and 3} & \multicolumn{3}{|c|}{ Study 4} & $\begin{array}{l}\text { Williams } \\
\text { and Hewitt } \\
(1979)\end{array}$ & $\begin{array}{c}\text { van Weerden } \\
\text { and Huisman } \\
\\
(1985)\end{array}$ & $\begin{array}{l}\text { Toullec } \\
\text { (1989) }\end{array}$ & $\begin{array}{l}\text { Gerrits } \\
\text { et al. } \\
\text { (1997) }\end{array}$ \\
\hline $\begin{array}{l}\text { Calf age, wk } \\
\text { Cal ADG, kg }\end{array}$ & & $\begin{array}{c}0 \text { to } 4 \\
0.45 \text { to } 0.4\end{array}$ & & & $\begin{array}{c}0 \text { to } 4 \\
0.57\end{array}$ & & $\begin{array}{c}6 \text { to } 14 \\
0.25\end{array}$ & $\begin{array}{c}5 \text { to } 7 \\
0.9\end{array}$ & $\begin{array}{c}8 \text { to } 20 \\
1.0\end{array}$ & $\begin{array}{c}8 \text { to } 20 \\
1.0\end{array}$ \\
\hline AA & $\%$, as fed ${ }^{2}$ & Intake, $\mathrm{g} / \mathrm{d}$ & Ratio to Lys & $\%$, as fed ${ }^{3}$ & Intake, $\mathrm{g} / \mathrm{d}$ & Ratio to Lys & & Ratio to Lys & & \\
\hline Lys & 2.34 & 15.9 & 1.00 & 2.34 & 15.9 & 1.00 & 1.00 & 1.00 & 1.00 & 1.00 \\
\hline Thr & 1.84 & 12.5 & 0.79 & 1.45 & 9.9 & 0.62 & 0.63 & 0.50 & 0.60 & 0.66 \\
\hline Arg & 0.66 & 4.5 & 0.28 & 0.88 & 6.0 & 0.38 & 1.09 & 0.33 & 0.44 & 0.40 \\
\hline Glu & 4.40 & 30.0 & 1.88 & 3.57 & 24.3 & 1.52 & - & - & - & - \\
\hline His & 0.49 & 3.3 & 0.21 & 0.68 & 4.6 & 0.29 & 0.38 & 0.25 & 0.31 & 0.39 \\
\hline Ile & 1.49 & 10.2 & 0.64 & 1.40 & 9.5 & 0.60 & 0.44 & 0.62 & 0.67 & 0.43 \\
\hline Leu & 2.65 & 18.0 & 1.13 & 2.46 & 16.8 & 1.05 & 1.08 & 0.87 & 1.02 & 1.12 \\
\hline Phe & 0.82 & 5.6 & 0.35 & 1.20 & 8.2 & 0.51 & - & - & - & 0.59 \\
\hline
\end{tabular}

${ }^{1}$ No starter, only MR was given to calves in the studies from the literature.

${ }^{2}$ Nutrient concentrations in the whey-based MR that maximized ADG.

${ }^{3}$ Nutrient concentrations in the skim-based MR in study 4 with the intermediate concentration of Thr.

studies in an unheated environment, their young age, the consumption of starter, and their lower intake of MR may explain their less efficient use of AA (NRC, 2001) compared with calves from the previous literature cited.

The NRC (2001) calf submodel was used to predict energy- and ADP-allowable ADG for each study. For these predictions, average BW, MR and starter intake, and average environmental temperature were used as inputs to the model. In each study, energy-allowable ADG was lower than ADP-allowable gain indicating that the model predicted energy to be the growth-limiting nutrient. The NRC model does not account for AA, so the model could not predict the differences in ADG observed from Lys and Met concentrations in the MR. The observed ADG increased $0.07 \mathrm{~kg} / \mathrm{d}$ between the calves fed the 24 and 28\% CP MR with no added Lys and Met in study 1 . However, the NRC (2001) calf submodel did not predict a response to increasing $\mathrm{CP}$ for these studies because energy was predicted to limit ADG. In studies 1, 2, and 3, predicted ADG was greater than measured ADG. Environmental temperatures were set to 18,13 , and $12^{\circ} \mathrm{C}$ in studies 1,2 , and 3 , respectively. In study 4 , measured $\mathrm{ADG}$ was greater than predicted ADG. Average temperature in study 4 was $-6^{\circ} \mathrm{C}$, which increased the maintenance energy requirement by $40 \%$ and therefore would lower the energy-allowable gain. The difference in energy-allowable $\mathrm{ADG}$ when the temperature changed from $20^{\circ} \mathrm{C}$ (ther- moneutral) to $-6^{\circ} \mathrm{C}$ was $0.36 \mathrm{~kg} / \mathrm{d}$. Temperatures of 10 and $11^{\circ} \mathrm{C}$ would have yielded predicted energy-allowable ADG of 0.52 and $0.59 \mathrm{~kg} / \mathrm{d}$, respectively, closer to the actual ADG of $0.57 \mathrm{~kg} / \mathrm{d}$. For these studies, the NRC (2001) model did not accurately predict ADG and was not responsive to the changes resulting from increasing the $\mathrm{CP}$ of the diet. Although the environmental temperature adjuster decreases predictions of $\mathrm{ADG}$ from the NRC (2001) calf submodel, other errors in the model structure must occur. The overestimation by NRC (2001) could be explained by either an underestimation of the energy requirement for maintenance or an overestimation of the digestibility of the nutrients for very young calves.

The NRC (2001) uses a fixed and high biological value for the CP of milk protein-based MR (0.80) and a high conversion of CP to ADP (0.93) and states that those values are too high for very young calves. This is confirmed by the results of the current studies and this topic has been discussed by Van Amburgh and Drackley (2005). Assuming that the conversion of CP from whey to ADP is $85 \%$ in very young calves (Tanan, 2005), a biological value can be calculated for each treatment so that the requirement of $\mathrm{ADP}$ for the observed $\mathrm{ADG}$ matches the supply of ADP. The improvement in ADG observed with the supplementation of synthetic AA cannot be predicted by the NRC (2001) system. In study 1 , the CP of the MR with 24 and $26 \% \mathrm{CP}$ without synthetic AA and the $28 \%$ CP MR with or without synthetic 
AA would present a biological value of 0.66 to 0.68 . For the MR with 24 and $26 \%$ synthetic AA, the biological value would be approximately 0.75 . Those values are similar to the range in biological values (0.67 to 0.72 ) from Terosky et al. (1997), as referenced in NRC (2001), using both whey and skim milk protein. Those biological values are also similar to estimates of Diaz et al. (2001), Blome et al. (2003), and Bartlett et al. (2006) that ranged from 0.63 to 0.75 using whey proteins.

\section{CONCLUSIONS}

The response to added Lys and Met in study 1 was large (approximately 17\%). The responses to added Met in studies 2 and 3 were 13 and $7 \%$, respectively; a smaller response than in study 1 , although the Met deficiency was smaller. These large responses to added AA show the need to formulate MR for Lys and Met, and not just CP. Feeding calves $0.68 \mathrm{~kg}$ of a whey-based MR with synthetic Lys and Met that was $26 \% \mathrm{CP}, 17 \%$ fat, $2.34 \%$ Lys, $0.72 \%$ Met, $1.27 \%$ Met+Cys, and $1.8 \%$ Thr maximized ADG and efficiency. Feeding calves 4 to $11 \%$ more $\mathrm{CP}$ and all essential AA did not improve $\mathrm{ADG}$ and efficiency. For calves less than $5 \mathrm{wk}$ old, averaging $48 \mathrm{~kg}$ of BW, consuming $204 \mathrm{~g}$ of $\mathrm{CP} / \mathrm{d}$, and gaining $0.46 \mathrm{~kg}$ of $\mathrm{BW} / \mathrm{d}$, their requirements appeared to be met with $17 \mathrm{~g}$ of Lys, 0.31 Met to Lys ratio, 0.54 Met+Cys to Lys ratio, and a Thr to Lys ratio less than 0.60 .

\section{REFERENCES}

AOAC. 2000. Official Methods of Analysis. 17th ed. Association of Offical Analytical Chemists, Arlington, VA

Bartlett, K. S., F. K. McKeith, M. J. VandeHaar, G. E. Dahl, and J. K. Drackley. 2006. Growth and body composition of dairy calves fed milk replacers containing different amounts of protein at two feeding rates. J. Anim. Sci. 84:1454-1467.

Blome, R. M., J. K. Drackley, F. K. McKeith, M. F. Hutjens, and G. C. McCoy. 2003. Growth, nutrient utilization, and body composition of dairy calves fed milk replacers containing different amounts of protein. J. Anim. Sci. 81:1641-1655.

Diaz, M. C., M. E. Van Amburgh, J. M. Smith, J. M. Kelsey, and E. L. Hutten. 2001. Composition of growth of Holstein calves fed milk replacer from birth to 105-kilogram BW. J. Dairy Sci. 84:830-842.
FASS. 1999. Guide for the Care and Use of Agricultural Animals in Agricultural Research and Teaching. 1st rev. ed. Federation of Animal Science Societies, Savoy, IL.

Gerrits, W. J. J., J. France, J. Dijkstra, M. W. Bosch, G. H. Tolman, and S. Tamminga. 1997. Evaluation of a model intergrating protein and energy metabolism in preruminant calves. J. Nutr. 127:1243-1252.

Hill, T. M., J. M. Aldrich, R. L. Schlotterbeck, and H. G. Bateman II. 2006a. Effects of feeding calves different rates and protein concentrations of twenty percent fat milk replacers on growth during the neonatal period. Prof. Anim. Sci. 22:252-260.

Hill, T. M., J. M. Aldrich, R. L. Schlotterbeck, and H. G. Bateman II. 2006b. Effects of feeding rate and concentrations of protein and fat of milk replacers fed to neonatal calves. Prof. Anim. Sci. $22: 374-381$

Hill, T. M., J. M. Aldrich, R. L. Schlotterbeck, and H. G. Bateman II. 2007a. Protein concentration for starters fed to transported neonatal calves. Prof. Anim. Sci. 23:123-134.

Hill, T. M., J. M. Aldrich, R. L. Schlotterbeck, and H. G. Bateman II. 2007b. Amino acids, fatty acids, and fat sources for calf milk replacers. Prof. Anim. Sci. 23:401-408.

Hill, T. M., J. M. Aldrich, R. L. Schlotterbeck, and H. G. Bateman II. 2007d. Effects of feeding rate of milk replacers and bedding material for calves in a cold, naturally ventilated nursery. Prof. Anim. Sci. 23:656-664.

Hill, T. M., H. G. Bateman II, J. M. Aldrich, and R. L. Schlotterbeck. $2007 \mathrm{c}$. Effects of the feeding rate of high protein calf milk replacers. Prof. Anim. Sci. 23:649-655.

Jenkins, K. J., and D. B. Emmons. 1983. Fortification of calf milk replacers with amino acids in free form or plastein-bound. Can. J. Anim. Sci. 63:893-903.

Kanjanapruthipong, J. 1998. Supplementation of milk replacers containing soy protein with threonine, methionine, and lysine in the diets of calves. J. Dairy Sci. 81:2912-2915.

National Research Council. 2001. Nutrient Requirements of Dairy Cattle. 7th rev. ed. Natl. Acad. Sci., Washington, DC.

Tanan, K. G. 2005. Nutrient sources for liquid feeding of calves in calf and heifer rearing. Pages 113-134 in Principles of Rearing the Modern Dairy Heifer from Calf to Calving. P. C. Garnsworthy, ed. Nottingham University Press, Nottingham, UK.

Terosky, T. L., A. J. Heinrichs, and L. L. Wilson. 1997. A comparison of milk protein sources in diets of calves up to eight weeks of age. J. Dairy Sci. 80:2977-2983.

Toullec, R. 1989. Veal calves. Pages 109-119 in Ruminant NutritionRecommended Allowances and Feed Tables. R. Jarrige, ed. INRA, London, UK.

Van Amburgh, M., and J. Drackley. 2005. Current perspectives on the energy and protein requirements of the pre-weaned calf. Pages 67-82 in Principles of Rearing the Modern Dairy Heifer from Calf to Calving. P. C. Garnsworthy, ed. Nottingham University Press, Nottingham, UK.

van Weerden, E. J., and J. Huisman. 1985. Amino acid requirement of the young veal calf. J. Anim. Physiol. Anim. Nutr. (Berl.) $53: 232-244$.

Williams, A. P., and D. Hewitt. 1979. The amino acid requirements of the preruminant calf. Br. J. Nutr. 41:311-319. 